\title{
The Neglected Fluidity Control Tool: Short-term National Debt
}

\author{
Wei Shen \\ Industrial and Commercial Management College, North China Electric Power University \\ Beijing 102206, China \\ E-mail: Shenwei_1965@126.com
}

\begin{abstract}
In this article, we first analyze the process of the fluidity control of short-term national debt and think that the short-term national debt market with certain scale can reduce the impact of fluidity to commercial banks, then compare three tools usually used in open market operations, i.e. middle and long term national debt, central bank bill and short-term national debt and the results show that the control ability of fluidity of short-term national debt is better than middle and long term national debt and central bank bill. However, the finance function of short-term national debt has ignored in China for a long time, which induces the actuality that the scale of short-term national debt is too small, and this actuality has produced a series of restriction effects to the control of fluidity. Therefore, we advice that relative departments should emphasize the finance function of short-term national debt, perfect the issuance system of short-term debt, and fully exert the control function of short-term national debt.
\end{abstract}

Keywords: Short-term national debt, Fluidity, Open-market operations

At present, the durative inflation occurs in the operation of China macro-economy. To control the surplus coin quantity and restrain the inflation, China central bank has adopted a series of corresponding macro-economic control measures such as expanding the issuance scale of central bank bill, enhancing the required deposit reserve ratio and enhancing the interest rate. China Ministry of Finance also issued 60 billions Yuan special national debt to retrench the fluidity in order to help the macro-economic control in 2007. However, one main operation tool to control the fluidity in western countries with market economy, the short-term national debt is not fully utilized in China macro-economic control, so it can not exert its function in the macro-economic control, which cannot but be emphasized and considered by us.

\section{The fluidity control process of short-term national debt}

To clearly describe the fluidity control process of short-term national debt, we suppose two situations.

The first situation: suppose the finance investment channels of one country have only two sorts including putting money in commercial bank and purchasing stock in the stock market. And all investors in that country put $1 / 2$ of cash capital (X) in commercial bank and use 1/2 of cash capital to purchase stock. When the stock market is in the downturn, investors sell part of stock and withdraw part of cash capital $(\Delta \mathrm{X})$ and put them in the commercial bank to avoid the stock risk. When the above hypothesis comes into existence, the cash capital flow of investors in this country is seen in Figure 1.

From Figure 1, the capital amount $\Delta \mathrm{X}$ that flows from the stock market to commercial bank is more, the new-adding deposit absorbed by commercial bank is more, and under the function of deposit multiplier, the derivative deposit scale of commercial bank is more, i.e. the fluidity impact suffered by commercial bank is more.

The second situation: suppose the country adds a invest channel, the short-term national debt market. When the stock market fluctuates and the cash flows out from the stock market, part investors will use the cash to purchase short-term national debt. Thus the investor can not only avoid the stock risk, but acquire stable and safe benefit. And because the short-term national debt has good cash-ability, when the stock market gets better over again, investors can quickly cash their short-term national debt and invest these money into the stock market and acquire returns with high risk. Under this situation, $\Delta \mathrm{X}$ will not flow back to the commercial bank system. Suppose $\Delta \mathrm{X}=\mathrm{X} 1+\mathrm{X} 2$, where the new-adding deposit of commercial bank is $\mathrm{X} 1$ and the part absorbed by the short-term national debt market is $\mathrm{X} 2$, and only $\mathrm{X} 2 \neq 0$, so there must be $\mathrm{X} 1<\Delta \mathrm{X}$. That is to say, under the situation adding a short-term national debt market, only the short-term national debt market absorbs part of capital flow that returns from the stock market to commercial bank, so the fluidity impact of stock return capital to commercial bank will be reduced.

It is obvious that the coin quantity flowing from the stock market to commercial bank X1 is negative correlative with the coin quantity flowing from the stock market to the short-term national debt X2. If Central Bank wants to reduce the coin quantity flowing to commercial bank, i.e. reduces $\mathrm{X} 1$, and reduce the credit scale created by commercial bank, it can close out its short-term national debt with magnetic price in the short-term national debt market and make the capital flowing out from the stock market flow to the short-term national debt market, i.e. add 
the quantity of X2. As a result, because the new-adding deposit of commercial banks is few, the new-adding loan scale will be restrained naturally and Central Bank will achieve the attention to control the fluidity, which is seen in Figure 2 .

Comparing the first situation with the second situation, we can see that the short-term national debt market serves as a shunt station that the stock capital enters into the commercial bank system in fact, and acts as a port for the risk capital. Therefore, if one country has developed and convenient short-term national debt market, quite part of capital in the stock part will be unnecessary to flow back to the commercial bank system, only flow between the stock market and the short-term national market. The short-term national debt market is more developmental, the X2 flowing out will be more and the impact of X1 to the fluidity of commercial bank is smaller.

\section{Comparisons of fluidity control among short-term national debt, middle and long term national debt and central bank bill}

In the country that the short-term national debt market is undeveloped, central bank always uses middle and long term national bank and central bank bill to replace the short-term national debt to develop the open market operations and control the fluidity, and that will acquire certain effects. But in fact, these three tools are very different to impact the effect of fluidity control.

\subsection{Comparison between short-term national debt and middle and long term national debt}

When central bank uses middle and long term national debt to control the surplus fluidity, some problems will occur. When the evidence of inflation occurs, the public will anticipate the market interest rate will be ascending and the national debt price will fall, so the public make for selling out national debt, and at this time, facing the pressure of inflation, central bank needs to deflate the money and also sell out middle and long-term national debt. As a result, the same-directional operations of central bank and the public may induce the bond sold by central bank can not achieve the anticipated sale quantity, and the intention of deflating the money will not be achieved certainly. To overcome above deficiencies, central bank may initiatively reduce its own yield when it sells the bond, and enhance the purchaser's yield in order to achieve the anticipated control objective. Thus the cost of open market operations will be enhanced invisibly.

If central bank uses short-term national debt to implement open market operations and control the fluidity, the effect will obvious better than middle and long term national debt. Because the short-term national debt has short term, high security and strong fluidity, it is regarded as "quasi-coin" by the public. For investors, the short-term national debt almost has any risk of interest rate, and its interest rate can fluctuate with the market interest rate and be adjusted in time, and investors will not suffer the lose of interest rate in the trade. Therefore, under the macro-economic background of surplus fluidity and inflation and the anticipation that the market interest rate will further rise, to avoid the risk of interest rate, investors always more use their leisured capital to purchase short-term national debt. Therefore, central bank uses short-term national debt to implement open market operations, which can not only excessively increase the cost of open market operations, but more flexibly adjust the sale direction and scale than middle and long term national debt to achieve the control objective with continual operation and small adjustment unconsciously. Above advantages of short-term national debts make it become into the first choice of tools in open-market operations. In US Federal Reserve, the asset of national debt occupies $80 \%$ of it total assets, and the proportion of short-term national debt in national debt assets can achieve about 43\%. In 1980-2001, the proportion of the amount of short-term national debt purchased by US Federal Reserve in all purchase amount of national debt was averagely $58.62 \%$ in its open market operations.

\subsection{Comparison between short-term national debt and central bank bill}

On the surface, there are many similar characters between short-term national debt and central bank bill. First, for the credit class, though their issuance principal parts are different, i.e. one is issued by Ministry of Finance, and the other is issued by central bank, but their credit classes are same, and they all belong to state-class credit, so they all possess higher security. Second, for the term, the short-term national debt is the national debt that the term doesn't exceed one year, and the central bank bill is also short-term usually, so both fluidity and marketability are good. But in fact, both sides have very large differences. First, the central bank bill is issued by central bank, so the central bank can independently decide the issuance time and amount according to the demands, which is propitious to adjust the accommodated amount of basic money flexibly. However, the deficiencies of central bank bill are obvious. First, because the range of holder is narrow (limited in banks and other finance institutions, and the public can not participate) and the term structure is single and it can not be cashed at any time, so the active degree of trade and the range and power of control will be discounted. Second, the abundant central bank bill issuance will increase the loss of central bank, and the capital is circulated in the interior of central back, the social benefits and the economic benefits are limited, and the payout of interest rate will also form putting of basic money. Third, the abundant central 
bank bill has "extruding" effect to develop other finance tools, which goes against the developments of the coin market and the capital market.

In the next place, because the short-term national debt is issued by Ministry of Finance, so if central bank wants to use the debt tool to manage coin, it needs to communicate and harmonize with finance departments, which is different to the issuance of central bank bill, and central bank can self decide. However, as the tool of open market operations, the short-term national debt has many advantages that central bank bill can not assimilate. First, the holders of short-term national debt are extensive, the term is multiple, and the marketability and the fluidity are strong, which cam make for trading and central bank can sell and purchase at any moment, implement continual operations and minimal adjustment to achieve the best control effects. Second, the capital to issue the short-term national debt will be associated with entity economy and produce certain social benefits and economic benefits whether it is used to fetch up deficit or invested into the economic construction. Third, the short-term national debt belongs to the financing tool in the coin market, so the issuance of short-term national debt is propitious to develop the coin market.

Because the short-term national debt and the central bill have respectively their characters, so when the administration of one country decides which one is the main operation tool of open market operations, it should consider whether the subjective conditions allow central bank to take short-term national bank as the operation tool in the short term, and it should consider which one in these two tools more suits for the control of coin policy and more makes for the development of finance market in the long term.

\section{The actuality of China short-term national debt and its restriction to fluidity control}

Because the short-term national debt possesses its special advantages to control the fluidity, the western countries with developed market economy very emphasize the issuance of short-term national debt. In US the short-term national debt implements roll issuance, the term variety is complete, and the issuance scale is large, which can achieve about $40 \%$ of total size of national debt issuance. Since China first issued short-term national debt in 1994, up to 2006, the average proportion that the issuance scale of short-term national debt in total scale of national debt issuance was only $9.9 \%$ (seen in Table 1). And in four years, the short-term national debt was not issued, and even in the year that the short-term national debt was issued, the real roll issuance was not formed.

Because the scale of short-term national debt in China is too small, this too small scale will form a sort of bottleneck effect, which will induce serious restrictions to many aspects of macro-economic control.

\subsection{The restriction to the effect of open-market operations}

When developed countries implement open market operations, most national debts are short-term national debts. The short-term bond has strong fluidity, and the central bank can purchase and sell at any moment, which makes the open market operations possesses characters of flexibility, mini-adjustment and continuity. Of course, central bank can buy middle and long term national debt through the mode of re-purchase to control the coin quantity in the circulation. Bu because the fluidity of middle and long term national debt is worse than the fluidity of short-term national debt and the risk is higher, so the operation effect is not better than short-term national debt. In China, because the scale of short-term national debt is too small, so central bank cannot but issue central bank bill to replace short-tem national debt to implement open market operations. Because the issuance range of central bank bill is limited, so the public can not participate, and it has very limited function to the withdrawal of coin in the circulation. And because the issuance of central bank bill, central back has suffered heavy interest rate, so the issuance scale must be considered, and it is also restrained by the interest rate. Thus, the effect to control the fluidity through open market operations will be discounted largely.

\subsection{The restriction to the fluidity guarantee of commercial bank}

Commercial banks of China would purchase national debt with quite quantities to keep the capital fluidity and reduce the interest difference. But the proportion of short-term national debt in China is low, so most national debts conceived by commercial banks are long-term national debts. Because the long term national debt has long term, high risk and bad marketability, so the long term national debt is not far convenient than short-term international debt to complement the fluidity. Otherwise, China implemented the policy of low interest rate all along in recent years, which make the interest rate of long term international debt very low all the while. In 2001, the average interest rate level of five-year-national debt was only above $0.25 \%$ than the deposit interest rate at the same term, and in 2002 and 2003, the average interest levels of three-year-national debt and five-year-national debt were even lower than the deposit at the same term. Under this background of low interest rate, the profit space that commercial banks purchase long term national debt is very narrow and even the loss will occur, furthermore, the present deposit interest rate of China has begin to rise, which makes the price of long term national debt hold by commercial banks fall and the opportunity cost increase, so the commercial banks cannot but assume the interest rate risk because of 
the rise of interest rate. If commercial banks hold the short-term national debt with certain quantities, so they can timely and conveniently adjust and quickly reduce the adverse influences brought by the invariance of interest rate according to the market. Therefore, it is very necessary to develop the short-term national debt market to strengthen the capital fluidity for commercial banks and prevent the interest rate risk that commercial banks hold single long term national debt.

\subsection{The restriction to extend money market scale and reduce capital market risk}

Comparing with the quick development of capital market, the development of coin market in China is relative lagged. To change this situation, first, abundant short-term national debts should be issued. The short-term national debt has high security, small ticket money, strong fluidity and few credit risk and market risk, so it is easier accepted by investors than business bill, cession deposit receipt and other coin market tools with high credit risk and market risk. Therefore, according to the actual situation of China finance market, the short-term national debt market should be quickly developed to drive the development of coin market, gradually drive the development of other short-term financing market, expand the scale of coin market, and promote the development of coin market.

The development of coin market can effectively detract the investment risk of capital market. The investment tools of capital market have long term, so they always have market risks with different degrees. Under the situation that the market has not short-mechanism and derivative tools to hedge the risk, the market risk accumulated in the capital market can not be released and detracted through reasonable channels. But to choose the financing toll of coin market, especially the short-term national debts to form the asset combination is a good path for investors. In a word, when the capital market develop to certain degree, if the there is no the development of coin market to support it, it is difficult to be further developed. Without corresponding coin market, the development of capital market will lack the adjustment mechanism to avoid risk and risk flow (Wu, Xiaoqiu, 2002). At present, the narrow short-term national debt of China can not promote the extension of the scale of coin market, and can not detract the risk of capital market.

\subsection{The restriction to the production of benchmark interest rate}

In the capital market, only the interest rate of the finance product with low risk and strong fluidity has qualification to serve as the basic interest of investment, and can be regarded as the reference of pricing for other finance assets. In all finance tools, the short-term national debt is the most proper one to accord with the requirement. Therefore, in some countries such as US, Japan and German with developed market economy, the yield of short-term national debt is served as the basic interest rate of the market interest. But in China, the basic interest rate is served by one-year-deposit interest rate, which is related with that the stated commercial banks have the supports of national credit. With the deepening of reform, commercial banks will finally be turned into enterprises really, and the risk of one-year-deposit interest rate will gradually occur, and it is exit from the stage of basic interest rate. So, which one will replace its position? At present, the inter-bank rate and the re-purchase interest rate of national debt seem to be further developed to basic interest rate. However, the participators in the inter-bank market are mainly commercial banks, and the cover range of market main body is not extensive, so it is difficult to comprehensively reflect the demand of market capital, and the re-purchase interest rate of national debt is influenced by the serious intersected system in China national debt market, so it is also can not form uniform interest rate level. Therefore, at present, these two interest rates can not be standard basic interest rate, and both all need some subjective economic conditions to better implement the function of basic interest rate (Wenbin, 2004). At present, China is in the sort of status lacking in basic interest rate, and this status is just one key factor to restrain the marketization of interest rate in China (Liyang, 2004). Because of the deficiency of basic interest rate, the price various finance tools in the finance market is difficult to be estimated reasonably, and investors can not operate capitals through the reasonable anticipation to the investment yield. To increase the issuance scale of short-term national debt and gradually cultivate the interest rate system taking the yield of short-term national debt as the basic interest rate has important actual meanings to promote the marketization of interest rate in China and become compatible with the world.

\section{Advices to extend China short-term national debt scale and enhance its fluidity control ability}

\subsection{Strengthening the cognitions to functions of short-term debt and optimizing the structure of national debt term}

For a long term, the function orientation of national debt in China is to emphasize its finance function, i.e. to fetch up finance deficit and raise construction capital, but the financing function of national debt, i.e. to control the macro-economy as the measure of open market operations, is not emphasized enough. The term of national debt to realize the finance function is best to be middle and long, and the term of national debt to realize the financing function is best to be short. Therefore, under the background to emphasize the finance function of national debt, the term structure of national debt forms a sort of abnormal structure with too large middle and long term proportion and too small short-term proportion. In future, we should strengthen the cognition to the financing function of short-term 
national debt and make the short-term national debt occupy a reasonable proportion in the total issuance scale of national debt.

\subsection{Further perfecting the national debt issuance system and gradually realizing the roll issuance of short-term debt}

Before 2006, China always adopted the annual circulation management system of national debt. Under this system, the annual circulation of national debt needed to be gradually examined and approved by National People's Congress, and once it was approved, it couldn't be easily changed. This system had been carried out in China for 24 years. Under this issuance system, the issuance of short-term national debt needs occupying the circulation of national debt in the same year. Therefore, as viewed from the bond distribution and relative interests, Ministry of Finance should issue more middle and long term national debt but not short-term national debt, and accordingly the short-term national debt was seriously lacked. Luckily, after 2006, China had begin to become compatible with the international method, and carried out the balance management system of national debt. Under this system, the compensative short-term national debt issued in the same year would not occupy the circulation of national debt, which creates conditions for the issuance of short-term national debt. But at present, because of the restrictions of various factors, the roll issuance system has not been formed. Various conditions to implement the roll issuance of short-term national debt should be created to make the issuance system of short-term national debt be perfected really. The roll issuance of short-term national debt is propitious to perfect the yield curve of national debt, and promote the marketization course of interest rate. The reference system of the yield curve of national debt is the necessary condition to reasonably price bond, credit and all finance products. However, because of the limitation of "small both ends" of term structure of national debt, the yield curve adopted by the market at present is obtained through the fitting of the statistical method, which is the main reason to induce bad veracity of product pricing in the bond market and difficult reasonable pricing of bank loan.

4.3 Strengthening the communication between China Ministry of Finance and China Central Bank, establishing the issuance harmony department of short-term national debt and constituting the issuance plan which can fulfill both demands

The short-term national debt is not only the tool of finance policy, but the tool of coin policy. Therefore, for the issuance scale of short-term national debt, the Ministry of Finance should strengthen communication and cooperation with central bank to make the issuance scale of short-term national debt can fulfill the demands of finance and financing at the same time. Based on this consideration, two departments can unite to establish the harmony institutions for the issuance of short-term national debt, constitute uniform issuance plan, and make the issuance scale of short-term national debt more reasonable and make the function of short-term national debt exerted to the largest extent.

\section{References}

Cao, Huxiao. (2003). Development of CHIBBM through STRIPS. Journal of Guangdong University of Finance. No.2.

Cheryl L Edwards. (1997). Open Market Operations in the 1990s. Federal Reserve Bulletin. November, 1997.

Dai, genyou. (2003). Practice and Experience of China Central Bank Open Market Operations. Journal of Financial Research. No.1.

Huangxian \& Zhaowei. (2003). Comparative Analysis of Open Market Operations between China and US. Journal of Financial Research. No.5.

Liyang, Wang, Guogang \& Wang, Songqi. (2004). China: Banking and Financial Development 2003. Beijing: Social Science Literature Press.

Machen. (2002). National Debt Market and Investment Research. Beijing: China Economic Press.

Weixuan. (2005). The Finance Issues Short-term National Debt to Measure Interest Rate and Promote Balance Management. China Business Post. Jan. 31, 2005.

Wenbin. (2004). Seven Sensitive Points Should Be Noticed When Selecting Benchmark Interest Rate. Shanghai Securities News. Dec. 9, 2004.

Yangtao. (2005). Policy Cooperation and System Harmony between Finance and Financing. China Economic Times. Nov., 2005. 
Table 1. Short-term national debt scale (hundred million Yuan) and the total proportion in the issuance scale of national debt $(\%)$

\begin{tabular}{|l|c|c|c|c|c|c|c|c|c|c|}
\hline \multicolumn{1}{|c|}{ Year } & 1994 & 1995 & 1996 & 2000 & 2002 & 2003 & 2004 & 2005 & 2006 & $1994-2006$ \\
\hline $\begin{array}{l}\text { Scale of short-term } \\
\text { national debt }\end{array}$ & 132.35 & 117.87 & 675 & 200 & 265.00 & 558.40 & 644.8 & 1396.5 & 2115.7 & 6105.62 \\
\hline $\begin{array}{l}\text { The total } \\
\text { proportion in the } \\
\text { issuance scale (\%) }\end{array}$ & 11.63 & 7.8 & 22.3 & 4.3 & 4.46 & 8.9 & 9.15 & 28 & 32 & 9.9 \\
\hline
\end{tabular}

Data source: Relative data from "The Quarterly Statistical Bulletin of People's Bank of China" and "China Securities Journal"

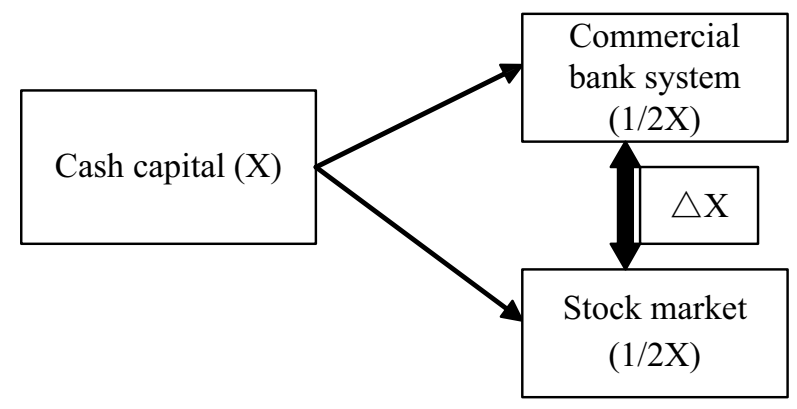

Figure 1. Investor's Cash Capital Flow

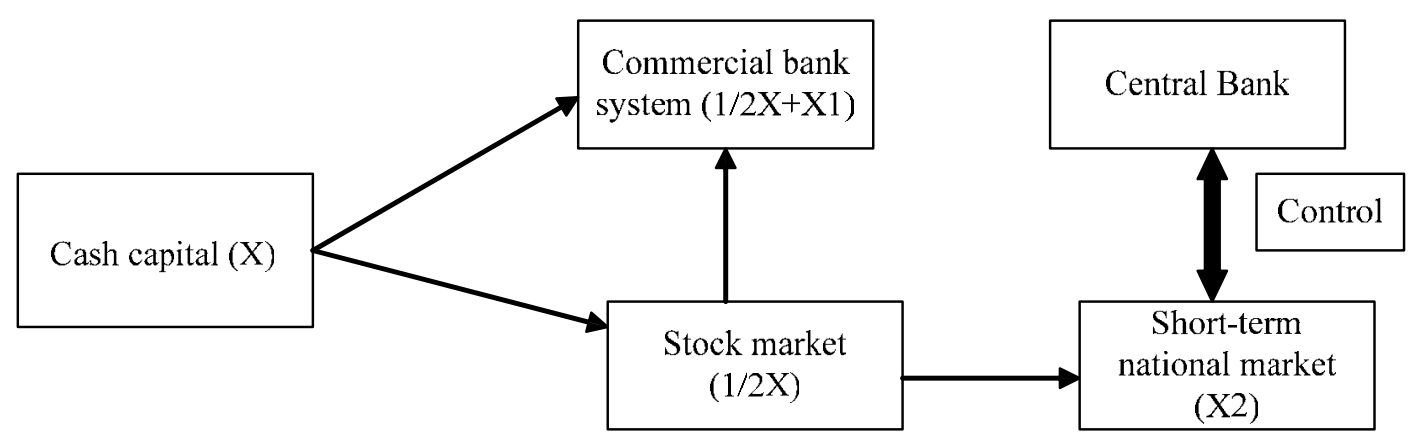

Figure 2. China Central Bank Controls the Fluidity 